\title{
KEBIJAKAN FORMULASI KEADILAN RESTORATIF DALAM SISTEM PERADILAN PIDANA ANAK
}

\author{
Oleh \\ I Made Wahyu Chandra Satriana Program \\ Magister, Program Studi Ilmu Hukum Program \\ Pascasarjana, Universitas Udayana
}

\begin{abstract}
ABSTRAK
Pembahasan pada jurnal ini mengangkat mengenai Kebijakan Formulasi Keadilan Restoratif Dalam Sistem Peradilan Pidana Anak. Adapun tujuan yang ingin dicapai dari penelitian ini yaitu agar dapat menganalisa dengan baik ide dasar yang terdapat dalam keadilan restoratif, kaitannya dengan anak yang berhadapan dengan hukum serta dapat menganalisis kebijakan formulasi yang diatur dalam UU No. 11 Tahun 2012 tentang Sistem Peradilan Pidana Anak untuk mewujudkan keadilan restoratif terhadap anak yang berhadapan dengan hukum. Sedangkan jenis penelitian yang digunakan dalam jurnal ilmiah ini adalah jenis penelitian hukum normatif, karena berdasarkan penilaian bahwa terdapat konflik norma antara UU No. 11 Tahun 2012 tentang Sistem Peradilan Pidana Anak dengan norma yang terdapat dalam Kitab Undang - Undang Hukum Pidana (KUHP). Dalam hal ini terhadap perbuatan melawan hukum yang dilakukan oleh anak yang belum genap berusia 18 (delapan belas tahun) dilakukan upaya diversi yang mempunyai tujuan agar terciptanya keseimbangan fokus perhatian antara kepentingan pelaku dan korban serta memperhatikan pula dampak penyelesaian perkara pidana yang terjadi di masyarakat untuk menjamin dan melindungi anak serta hak-haknya agar dapat hidup, tumbuh, berkembang dan berpartisipasi secara optimal sesuai dengan harkat dan martabat kemanusiaan, serta mendapat perlindungan dari kekerasan dan diskriminasi.
\end{abstract}

Kata Kunci : Kebijakan Formulasi, Keadilan Restoratif dan Perlindungan Anak 


\section{ABSTRACT}

The discussion on this journal raised regarding policy formulation Restorative Justice in the Criminal Justice System Children. The objectives of this research that in order to properly analyze the basic ideas contained in restorative justice, to do with children in conflict with the law and to analyze policy formulation set forth in the Law. 11

2012 on the Criminal Justice System Kids for restorative justice to children in conflict with the law. While this type of research used in scientific journals this is the kind of normative legal research, because it is based on the assessment that there is a conflict between the norms of Law. 11 of 2012 on the Criminal Justice System Children with the norms contained in the draft - Criminal Code (Criminal Code ). In this case the unlawful act committed by the child who has not reached the age of 18 (eighteen years) diversion efforts which have the purpose for the creation of a balance between the interests of focus and attention to the perpetrator and the victim also impact the completion of the criminal case that happens in the community to ensure and protecting children and their rights in order to live, grow, develop and participate optimally in accordance with the dignity of humanity, as well as protection from violence and discrimination .

Keywords : Policy Formulation, Restorative Justice and Child Protection . 


\section{PENDAHULUAN}

\subsection{Latar Belakang}

Periode anak-anak adalah masa dimana anak belum mandiri, belum memiliki kesadaran penuh akan perbuatannya, kepribadian masih labil atau pribadi yang belum terbentuk secara utuh yang sangat rentan dalam kondisi mental dan kejiwaaan. Dengan kata lain keadaan psikologinya masih labil, tidak independent, dan mudah terpengaruh oleh kondisi disekitarnya. Dengan kondisi demikian perbuatan yang dilakukan oleh anak tidak sepenuhnya dapat dipertanggungjawabkan, karena anak sebagai pelaku bukanlah sebagai pelaku murni akan tetapi dapat juga sebagai korban.

Berdasarkan bahan hukum yang diperoleh terhadap kasus kejahatan anak sebagai pelaku di POLDA Bali beserta jajarannya untuk periode bulan Januari sampai dengan Desember 2012, tercatat 19 kasus penganiayaan, kemudian pencurian sebanyak 33 kasus, dan kasus-kasus lainnya seperti melarikan perempuan terdapat 1 kasus, persetubuhan 5 kasus, pelecehan seksual 4 kasus, dan pornografi 1 kasus. ${ }^{1}$ Sedangkan anak sebagai pelaku kekerasan di POLDA Bali untuk periode yang sama terdapat 120 kasus.

PBB telah mengesahkan Konvensi Hak Anak. ${ }^{2}$ Konvensi ini adalah merupakan suatu komponen internasional yang secara yuridis mengikat negara-negara yang telah meratifikasi agar mewujudkannya serta Negara-negara tersebut mempunyai kewajiban hukum internasional untuk menerapkannya ke dalam aturan-aturan hukum positif masing-masing Negara, sehingga berlaku dan mempunyai kekuatan hukum mengikat ke dalam.

Konvensi Hak Anak.

Penjabaran isi dan jiwa Convention on the Rights of the Child dalam undang-undang pidana di Indonesia, dapat dilihat pada Undang-Undang RI Nomor 23 Tahun 2002 tentang Perlindungan Anak.

${ }^{1}$ Kasubdit IV, Kepolisian Negara RI Daerah Bali Dir. Reserse Kriminal Umum

${ }^{2}$ Konvensi Hak Anak (UN's Convention on the Rights of the Child) tanggal 20 November 1989, memuat 4 (empat) prinsip dasar hak-hak anak yaitu: hak hidup; Hak kelangsungan hidup atau tumbuh kembang; kepentingan terbaik anak; Hak partisipasi/ mengemukakan pendapat. 
Di dalam hukum pidana terdapat suatu pendapat bahwa seseorang tidak dapat dihukum karena melakukan suatu kesalahan, apabila sebelum ia melakukan kesalahan itu belum ada undang undang yang menyatakan bahwa kesalahan yang diperbuatnya itu diancam dengan hukuman (Nullum Delictum, Nulla Poena Sine Praevia lege Poenali). Asas ini terdapat dalam Pasal 1 ayat (1) KUHP. ${ }^{3}$

Penerapan Pidana yang lazim berdasarkan Kitab Undang - Undang Hukum Pidana (KUHP) tidak mendidik anak menjadi lebih baik, melainkan dapat memperburuk kondisi serta dapat meningkatkan tingkat kejahatan anak. Hal ini disebabkan karena paradigma aparat penegak hukum yang mengganggap anak tersebut sebagai anak nakal dan bukan sebagai korban melainkan semata-mata sebagai pelaku tindak pidana.

Kisah seorang anak yang bernama Muhammad Azwar atau yang dikenal dengan nama Raju, sebagai pelaku penganiayaan dan

\footnotetext{
${ }^{3}$ Pasal 1 ayat (1) KUHP menentukan bahwa: tiada suatu perbuatan dapat dipidana kecuali atas kekuatan aturan pidana dalam perundang-undangan yang telah ada, sebelum perbuatan dilakukan.
}

diadili di Pengadilan Negeri Stabat Cabang, Pangkalan Brandan, Kabupaten Langkat, Sumatera Utara. Kasus Raju ini mendapat perhatian publik khususnya pada penahanan Raju didalam tahanan orang dewasa dan didalam persidangan, hakim mengenakan seragam. Kasus lain yang juga melibatkan anak adalah upaya kasasi yang dilakukan Jaksa Penuntut Umum pada sidang lanjutan pembacaan putusan sela dan memvonis bebas siswa SMP yang dituduh mencuri voucher pulsa senilai Rp. 10 ribu, alasannya Jaksa Penuntut Umum masih menganut asas legalitas.

Kedua kasus didekatkan dengan sebuah pendekatan yang legalistik formal, sehingga mengabaikan pendekatan psikologis dan sosiologis, dimana Negara melalui Badan Pemasyarakatan (BAPAS) seharusnya sangat berperan untuk melakukan penelitian kemasyarakatan dan menjadi pertimbangan utama untuk memutuskan sanksi hukum sehingga akan ditemukan bentuk rehabilitasi bagi anak yang bermasalah/ berhadapan dengan hukum. 
Perlindungan anak yang berhadapan dengan hukum sangat diperlukan, mengingat anak yang berhadapan dengan hukum berada pada situasi dan kondisi diluar kemampuan mental dan psikisnya serta dalam proses pemeriksaan pada tahap penyidikan, penyidik hanya melihat kepentingan proses hukum tanpa memperhatikan kepentingan dan kesejahteraan anak. Untuk itu harus mendapat perlindungan hukum, mengingat mereka sangat peka terhadap berbagai ancaman gangguan mental, fisik dan sosial.

Keadilan yang selama ini berlangsung dalam sistem peradilan pidana di Indonesia adalah retributive justice atau keadilan retributif, sedangkan yang diharapkan adalah restorative justice atau keadilan restoratif, yaitu suatu proses dimana semua pihak yang terlibat dalam suatu tindak pidana tertentu bersama-sama memecahkan masalah, bagaimana menangani akibatnya dimasa yang akan datang.

Dalam UU No. 11 tahun 2012 tentang Sistem Peradilan Pidana Anak, menganut konsep keadilan restoratif yang diwujudkan melalui upaya diversi. Keadilan
Restoratif adalah model penyelesaian perkara pidana yang mengedepankan pemulihan kembali terhadap korban, pelaku, dan masyarakat. Tujuan keadilan restoratif adalah adanya partisipasi korban dan pelaku, partisipasi warga sebagai fasilitator dalam penyelesaian kasus, sehingga ada jaminan anak atau pelaku tidak lagi mengganggu harmoni yang sudah tercipta di masyarakat.

Keadilan restoratif, dapat terwujud melalui: mediasi antara korban dengan pelaku, musyawarah keluarga korban dan keluarga pelaku, dan pelayanan di masyarakat yang bersifat pemulihan baik bagi korban maupun pelaku.

Keadilan restoratif adalah salah satu alternatif penyelesaian sengketa diluar pengadilan atau dikenal dengan istilah Alternatif Dispute Resolution/ADR. ADR pada umumnya digunakan dilingkungan kasus-kasus perdata, tidak untuk kasus-kasus Pidana.

Dalam proses peradilan pidana anak, yang diharapkan adalah proses yang dapat memulihkan, artinya perkara ditangani oleh penegak hukum yang mempunyai minat, perhatian, dedikasi dan 
memahami masalah anak, dan telah mengikuti pelatihan mewujudkan keadilan restoratif, serta apabila terjadi penahanan terhadap anak yang berhadapan dengan hukum maka harus memperhatikan prinsip prinsip dasar dari konvensi hak-hak anak yang telah diadopsi kedalam UU Perlindungan Anak

Berdasarkan pada uraian latar belakang tersebut di atas, dapat dirumuskan permasalahan yang diangkat dalam tulisan ini yaitu: Apakah ide dasar keadilan restoratif dalam sistem peradilan pidana anak? dan bagaimanakah kebijakan formulasi keadilan restoratif dalam Undang - Undang No. 11 tahun 2012 Tentang Sistem Peradilan Pidana Anak?

\section{Isi Makalah}

Ide dasar keadilan restoratif dalam sistem peradilan pidana anak merupakan suatu hal yang baru dalam sistem hukum pidana di Indonesia. Keadilan restoratif adalah keadilan terhadap anak yang bermasalah dengan hukum, baik anak sebagai pelaku, maupun anak sebagai korban. Hal ini mensyaratkan karena anak merupakan karunia Tuhan, yang rentan terhadap perlakuan diskriminasi dan belum mampu membela diri sendiri dan bertanggungjawab terhadap perbuatan yang dilakukannya sehingga memerlukan perlindungan hukum demi kepentingan terbaik anak. .

\subsection{Metode Penulisan:}

Dalam metode penulisan ini, menggunakan pendekatan masalah secara yuridis normatif yaitu pendekatan peraturan perundang undangan yang berhubungan dengan masalah yang dibahas. Bahan hukum dengan menggunakan metode studi pustaka (library research) dimana bahan hukum yang diperoleh dari literatur-literatur, buku-buku dan dokumen-dokumen yang berkenaan dengan masalah yang dibahas.

\subsection{Hasil dan Pembahasan}

\subsubsection{Kerangka Konseptual}

\section{Sistem Peradilan Pidana}

Anak

\section{Peradilan Pidana Anak}

Anak dalam peradilan pidana anak adalah anak yang berhadapan dengan hukum yaitu anak yang 
berkonflik dengan hukum, anak yang menjadi korban tindak pidana, dan anak yang menjadi saksi tindak pidana. Sistem peradilan pidana anak merupakan juga sistem peradilan pidana, maka di dalam memberikan pengertian sistem peradilan pidana anak, terlebih dahulu menguraikan tentang sistem peradilan pidana. Sistem peradilan pidana (Criminal justice system) menunjukkan cara kerja dalam menanggulangi tindak kejahatan dengan berdasarkan pendekatan sistematis yang didalamnya terdapat bagian-bagian yang merupakan subsistem antara lain: Instansi Kepolisian, Instansi Kejaksaan, Lembaga Peradilan dan Lembaga Koreksi (Lembaga Pemasyarakatan), yang mempunyai tujuan-tujuan antara lain tujuan jangka pendek yaitu memasyarakatkan kembali pelaku tindak pidana, tujuan jangka menengah yaitu mencegah terjadinya kejahatan, dan tujuan jangka panjangnya adalah untuk kesejahteraan sosial.

\section{Ide Dasar Keadilan Restoratif}

Konsep keadilan Restoratif telah ada sejak kurang lebih dua puluh tahun yang lalu sebagai pilihan dalam menyelesaikan perkara pidana anak. Organisasi Peradilan Anak Perserikatan Bangsa-Bangsa (PBB) memberikan pengertian restorative justice adalah suatu proses yang menuntut keterlibatan semua pihak yang berhubungan dengan tindak pidana tertentu agar mencari solusi bersama untuk memecahkan masalah dan memikirkan bagaimana mengatasi akibat pada masa yang akan datang. Restorative Justice pada dasarnya dilakukan melalui diskresi (kebijakan) dan diversi, yaitu menyelesaikan secara musyawarah dengan cara pengalihan perkara dari proses formal peradilan pidana ke proses nonformal untuk diselesaikan secara musyawarah.

\section{Sejarah Ide Dasar Keadilan Restoratif di Beberapa Negara}

Sebelum di Indonesia menerapkan keadilan restoratif, ternyata di beberapa Negara telah menerapkan konsep ini. Tidak hanya dalam aturan yang tertuang dalam KUHP Negara tersebut, tetapi terdapat dalam peraturan perundang 
- undangan yang lebih khusus. Sebagai contoh, asal-usul dari gerakan keadilan restoratif kontemporer secara tradisional yang ditelusuri oleh eksperimen di Kanada dengan melakukan mediasi antara korban-pelaku di Elmira, Ontario tahun 1974. Menurut sejarah, bahwa percobaan yang dilakukan oleh petugas Markus Yantzi (anggota radikal; sekte Kristen, Mennonities), yang frustrasi dalam proses untuk menangani para pelaku kriminal usia muda, memiliki Ide gemilang. Markus meminta hakim, pada kasus pengerusakan yang dilakukan oleh dua pemuda yang mengaku bersalah telah merusak 22 properti, untuk menyuruh pelaku menemui korbankorban mereka, di perusahaan Yantzi dan pemuda Mennonite, Dave Worth. Yang mengejutkan mereka, hakim setuju memerintahkan pelanggar untuk pergi ke Yantzi dan Worth bertemu korban dan membawa kembali laporan tentang kerusakan yang telah mereka alami.

Dari percobaan spontan idealis ini, keadilan restoratif dalam bentuk Program Rekonsiliasi Korban-Pelanggar (VORPs) lahir atau lebih tepatnya dimunculkan kembali karena sejarah mengatakan bahwa suatu klaim penting tentang keadilan restoratif adalah cara kuno untuk menangani kejahatan. Dalam VORPS, keadilan restoratif mengambil bentuk pertemuan antara korban dan pelaku, yang difasilitasi oleh mediator yang terlatih, yang dipilih dari relawan masyarakat. Penggunaan secara resmi pertama dari lingkaran hukum terjadi pada tahun 1992 di Pengadilan Teritorial Yukon Kanada. Hakim Barry Stuart yang menangani kasus pelanggaran, mengundang anggota masyarakat yang sebenarnya merupakan komunitas pelaku untuk berpartisipasi dalam lingkaran hukum. Dalam lingkaran hukum, komunitas orang yang tertarik mengambil bagian dalam diskusi tentang apa yang terjadi, mengapa itu terjadi, apa yang harus dilakukan tentang itu dan apa yang harus dilakukan untuk mencegah lebih lanjut insiden tersebut.

Hakim

kemudian memutuskan hukuman dengan membuat perintah dan rekomendasi, berdasarkan apa yang diusulkan oleh peradilan. Meskipun disebut lingkaran hukum, harus dibuat jelas 
bahwa diskusi dan keputusan berjalan dengan baik bahkan melampaui apa yang secara konvensional dicakup dalam proses hukuman. Secara khusus, lingkaran mengatasi masalah seperti sejauh mana tanggung jawab komunitas untuk mempertanggung jawabkan suatu kejahatan dan untuk melakukan sesuatu tentang hal itu.

Dalam kasus tersebut, komunitas pelaku menunjukkan bahwa mereka tidak ingin pelaku untuk di penjara dan bahwa mereka bersedia untuk membantu merehabilitasi pelaku. Hakim Stuart, yang bertindak atas keinginan masyarakat, memutuskan masa percobaan dua tahun dan pelaku menerima dengan mengubah hidupnya menjadi lebih baik.

Suatu bentuk 'keadilan asli' yang telah tersebar lebih luas adalah Konferensi Kelompok Keluarga atau Familly Group Conventions (FGC). FGCs diperkenalkan oleh undangundang di Selandia Baru pada tahun 1989 sebagai forum baru untuk menangani kejahatan remaja serta perawatan pemuda dan isu-isu perlindungan. FGCs serupa dengan VORPs yang konon diperkenalkan oleh praktisi keadilan dan filsuf suku Maori. Namun penyelesaian pelanggaran hukum dan kejahatan yang terjadi, jangkauan orang-orang yang terlibat dalam proses mediasi dalam FGCs lebih luas, meliputi anggota keluarga dari pelaku dan terkadang oleh orang lain yang memiliki hubungan perawatan dengan mereka. Korban juga membawa anggota dari badan-badan peradilan pidana seperti polisi. Perjanjian yang bertujuan untuk restitusi tidak hanya terlibat (represif) tetapi dirancang sebuah rencana aksi mengatasi penyebab (preventif) yang mendasari perilaku kejahatan dan dengan demikian mencegah kembali terjadinya kejahatan.

Pada awal tahun 1990-an polisi di Wagga Wagga, sebuah kota kecil di New South Wales, Australia memulai percobaan yang sangat dipengaruhi tidak hanya oleh FGCs Selandia Baru, tetapi juga oleh teori Jhon Braithwaite dari reintegrasi malu. Braithwaite berpendapat bahwa keluarga dan masyarakat yang malu diarahkan pada pelaku dalam kaitan menghormati pelanggar dan diikuti oleh upaya untuk reintegrasi 
mereka adalah bentuk yang sangat kuat dari kontrol sosial. Dalam "Model Wagga' FGCs dikonseptualisasikan sebagai forum di mana pelanggar akan dihadapkan dengan reintegrasi malu tersebut.

FGCs dan dengan model Wagga, mengalami perkembangan yang pesat dan menakjubkan. Saat itu diperkenalkan di Inggris pada pertengahan tahun 1990-an oleh seorang polisi bernama Thames Valley dan sejak itu telah diadopsi oleh banyak pasukan polisi Inggris lainnya. Meskipun telah ada percobaan yang berskala kecil dengan rekonsiliasi korban-pelaku di Inggris pada awal tahun 1980-an, dan meskipun Martin Wright telah menjelaskan ide-ide restoratif dan prinsip VORPS, itu hanya ketika polisi mulai bereksperimen dengan 'peringatan restoratif' bahwa gerakan keadilan restoratif benar-benar lepas landas di UK. Salah satu hasil dari ini bahwa, di Inggris keadilan restoratif telah erat diidentifikasi dengan teori 'reintegrasi malu' dari Braithwaite dan model konferensi Wagga.

Diantara beberapa aktivis keadilan restoratif di Inggris, yang mulai mengeksplorasi peluang diciptakan Undang-Undang Kejahatan dan Gangguan 1998 dan Undang-Undang Keadilan Pemuda dan Bukti Pidana 1999, untuk memperkenalkan keadilan restoratif dalam sistem peradilan remaja. Dalam upaya-upaya ini, pentingnya pengembangan atau berpegang pada suatu konsepsi yang lebih luas akan keadilan restoratif semakin ditekankan.

\section{Kebijakan Hukum Pidana}

Usaha pembaharuan hukum di Indonesia yang sudah dimulai sejak lahirnya UUD 1945, tidak dapat dilepaskan pula dari landasan dan sekaligus tujuan yang ingin dicapai seperti telah dirumuskan juga dalam pembukaan UUD 1945. Tujuan yang telah digariskan dalam UUD 1945, secara singkat adalah "melindungi segenap bangsa Indonesia dan untuk memajukan kesejahteraan umum berdasarkan Pancasila”. Inilah garis kebijakan umum yang menjadi landasan dan sekaligus tujuan politik hukum di Indonesia. Inipulalah yang menjadi landasan dan tujuan dari setiap usaha pembaharuan hukum, termasuk pembaharuan di bidang 
hukum pidana dan kebijakan penanggulangan kejahatan.

Penanganan terhadap anak yang berhadapan dengan hukum adalah bagian dari kebijakan atau upaya penanggulangan kejahatan karena tujuan utamanya adalah perlindungan anak dan mensejahterakan anak dimana anak merupakan bagian dari masyarakat.

Menurut Barda Nawawi Arief, kebijakan penegakan hukum pidana merupakan serangkaian proses yang terdiri dari tiga tahap kebijakan, yaitu

(1) tahap kebijakan legislatif/ formulatif;

(2) tahap kebijakan yudikatif/ aplikatif; dan

(3) tahap kebijakan eksekutif/ administratif. $^{4}$

Lebih lanjut dijelaskan bahwa dalam ketiga tahap kebijakan penegakan hukum pidana itu terkandung di dalamnya tiga kekuasaan/kewenangan, yaitu kekuasaan legislatif/formulatif dalam menetapkan atau merumuskan perbuatan apa yang dapat dipidana

${ }^{4}$ Barda Nawawi Arief III, 1998, Beberapa Aspek Kebijakan Penegakan dan Pengembangan Hukum Pidana, PT.Citra Aditya Bakti,Bandung,hal. 30, (selanjutnya disebut Arief Barda Nawawi III) dan sanksi apa yang dapat dikenakan;

kekuasaan yudikatif/aplikatif dalam penerapan hukum pidana; dan kekuasaan eksekutif/administratif dalam melaksanakan hukum pidana. ${ }^{5}$

\section{Pendekatan Integral Antara Kebijakan Penal dan Non Penal}

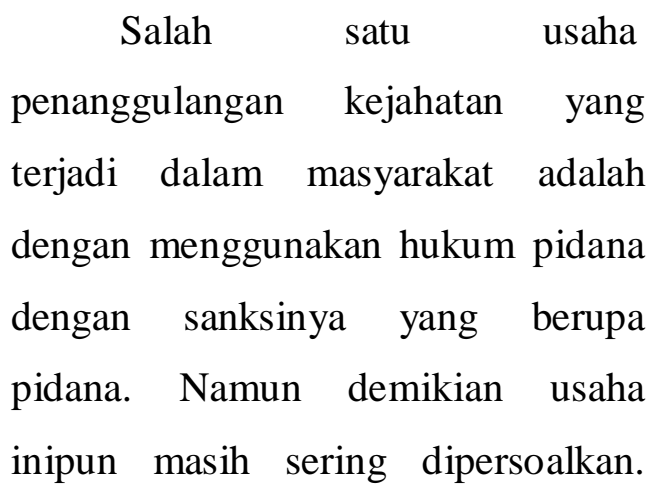
Perbedaan mengenai peranan pidana dalam menghadapi masalah kejahatan ini mempunyai dimensi hukum yang penting dalam rangka perlindungan masyarakat dan penegakkan hukum.

Konsepsi kebijakan penanggulangan kejahatan yang integral mengandung konsekwensi bahwa segala usaha yang rasional untuk menanggulangi kejahatan harus merupakan satu kesatuan yang terpadu. Ini berarti kebijakan untuk menanggulangi kejahatan dengan

${ }^{5}$ Ibid 
menggunakan sanksi pidana, harus pula dipadukan dengan usaha usaha lain yang bersifat non-penal.

Tujuan utama dari usahausaha non-penal ini adalah memperbaiki kondisi-kondisi sosial tertentu yang secara tidak langsung mempunyai pengaruh preventif terhadap kejahatan. Dengan demikian dilihat dari sudut politik kriminal, keseluruhan kegiatan preventif yang non-penal itu sebenarnya mempunyai kedudukan yang sangat strategis.

Dalam menangani perkara anak, anak korban, dan/atau anak saksi, pembimbing kemasyarakatan, pekerja sosial professional dan tenaga kesejahteraan social, penyidik, penuntut umum, hakim, dan advokat atau pemberi bantuan hukum lainnya tetap wajib memperhatikan kepentingan terbaik bagi anak dan mengusahakan agar tetap terciptanya suasana kekeluargaan dalam setiap tahapan proses pemeriksaan. Demikian juga dalam hal penjatuhan sanksi pidana terhadap anak yang berhadapan dengan hukum diupayakan agar tetap memperhatikan kepentingan terbaik bagi si anak.

\section{Kebijakan Formulasi \\ Hukum Pidana dalam Sistem Perumusan Sanksi}

Dalam kebijakan legislatif/ formulasi selama ini terlihat ada peluang yang memperbesar dijatuhkannya pidana penjara. Faktor pendorong yang utama bagi aparat penegak hukum dalam hal ini hakim menjatuhkan pidana penjara adalah adanya perumusan tunggal yang memuat ancaman penjara saja. Perumusan komulatif pada hakekatnya tidak berbeda dengan perumusan tunggal, karena mengandung keharusan untuk menjatuhkan pidana penjara bersama - sama dengan jenis sanksi pidana lainnya. Kebijakan dalam menetapkan sanksi pidana pada hakekatnya juga merupakan kebijakan untuk menerapkan atau mengoperasionalkan sanksi pidana.

Suatu kebijakan kriminal harus dapat mengintegrasikan dan mengharmonisasikan seluruh kegiatan preventif yang non-penal itu kedalam suatu sistem kegiatan Negara yang teratur dan terpadu. Sehubungan dengan hal tersebut, Radzinovicz menyatakan: kebijakan kriminal harus mengkombinasikan bermacam-macam kegiatan preventif itu dan mengaturnya sedemikian 
rupa sehingga membentuk suatu mekanisme tunggal yang luas dan akhirnya mengkoordinasikan keseluruhannya itu ke dalam suatu sistem kegiatan Negara-negara yang teratur. $^{6}$

Kebijakan legislatif pada hakekatnya juga merupakan kebijakan operasional yang berarti apabila penggunaan atau pengoperasionalisasian pidana penjara hendak dilakukan secara selektif atau limitatif dan mempunyai fleksibelitas, maka kebijakan yang dituangkan dalam perundangundangan haruslah bersifat sama. Dengan sistem perumusan tunggal ini, jelas tidak sesuai dengan ide dasar yang terdapat dalam sistem peradilan pidana anak yang mengedapankan keadilan restoratif. Selain itu tidak sesuai pula dengan ide dasar yang dikembangkan di Indonesia dengan sistem pemasyarakatan. Dengan masih adanya sistem perumusan tunggal ini, maka sebenarnya terkandung

\footnotetext{
${ }^{6}$ Karl O. Christiansen,1974. Some consideration on the Possibility of a Rational Criminal Policy. Resource Material Series No.7, UNAFEI, Tokyo. Hal. 74: "Criminal policy must combine the various preventive machine and finally coordinate the whole into an organized sistem of state activity"
}

didalamnya kontradiksi ide konsepsi pemasyarakatan yang bertolak dari ide rehabilitasi dan resosialisasi yang menghendaki adanya individualisasi dan kelonggaran dalam menetapkan pidana yang sesuai untuk terdakwa. Kelonggaran ini tidak hanya dalam arti menetapkan ukuran pidana (strafmaat) dan pelaksanaan pembinaannya (Strafmodus), tetapi juga dalam menetapkan jenis pidananya (strafsoort).

Dilihat dari sudut proses pengoperasionalisasian pidana penjara secara selektif dan fleksibel, perumusan ancaman pidana penjara yang bersifat perintah dan mutlak (imperative dan absolute) seperti halnya dengan perumusan tunggal dan komulatif, hanya dapat dibenarkan apabila disertai dengan perumusan kebijakan yang dapat memperlunak penerapan kebijakan yang sifatnya imperatif dan absolut itu. Perumusan kebijakan yang memperlunak perumusan kebijakan yang kaku itu dapat dirumuskan sebagai suatu kebijakan yang preventif maupun represif.

Kebijakan preventif adalah kebijakan yang diberikan oleh undang-undang kepada aparat 
penegak hukum untuk mencegah atau tidak mengajukan tersangka ke pengadilan. Jadi untuk mencegah kemungkinan besar terdakwa dikenakan pidana penjara sehubungan dengan adanya sistem perumusan ancaman pidana penjara yang bersifat imperatif. Menganai kebijakan preventif tersebut, diterapkan juga di beberapa Negara selain Indonesia yaitu: Jepang dan Polandia. Dalam sistem peradilan pidana di Jepang. Tidak semua perkara di Jepang oleh polisi diserahkan atau diteruskan ke Jaksa untuk dituntut. Begitu pula Jaksa berwenang untuk menunda penuntutan walaupun bukti-bukti telah cukup untuk melakukan penuntutan, adapun pertimbangannya adalah apabila tersangka menunjukkan penyesalan yang sungguh-sungguh dan menunjukkan tanda-tanda yang baik untuk menjadi warga masyarakat yang patuh pada hukum, serta tindak pidana yang mereka lakukan tidaklah demikian serius sehingga tindakan tidak memidana tidak akan mengganggu atau menyinggung perasaan moral masyarakat pada umunya. $^{7}$

Menurut Hiroshi Ishikawa, direktur UNAFEI di Tokyo Jepang, faktor-faktor yang termasuk dalam kelompok pertama (a) berhubungan dengan karakteristik pribadi si pelaku (the personal characteristics of offenders); kelompok kedua (b) berhubungan dengan pengaruh pencegahan umum dari pidana ("general derrence" effect of the punishment). Dan kelompok ketiga (c) berhubungan dengan pengaruh pencegahan khusus dari pidana ("special deterrence" effect of the punishment). Berdasarkan ketiga faktor diatas, maka menurut Ishikawa, penuntut umum di Jepang berwenang menguji perkara pidana tidak hanya dari sudut hukum, tetapi juga dari sudut politik kriminal. ${ }^{8}$

Kebijakan preventif juga dapat dilihat dalam perumusan bab IV pasal 27 - 29 KUHP Polandia, dengan judul conditional

\section{${ }^{7}$ Minoru Shikita, 1982. Integrated} Approach to Effective Administration of Criminal and Juvinille Justice, dalam Criminal Justice in Asia, UNAFEI. Hal. 37.

${ }^{8}$ Hiroshi Ishikawa, 1984.

Characteristic Aspects of Japannese Criminal Sistem - A Succesful Example of Integrated Approach, Seminar on the Prevention of Crime and the Treatment of Offenders, January 1984, Jakarta, hal. 11-12. 
Discontinuance of the Proceedings. Penghentian atau penundaan bersyarat (conditional dismissal atau conditional discontinuance) dari proses pidana

Dalam hal-hal tertentu dilihat dari sudut kepentingan si pelanggar dan bahkan juga dari sudut politik kriminal yang rasional, tidaklah cukup sederhana untuk menunda eksekusi pidana. Pemidaan oleh pengadilan mengharuskan disimpannya catatan atau riwayat kejahatan dari si pelanggar kedalam berkas, dan hal ini dapat menyebabkan kerugian yang tidak dapat diperbaiki bagi yang bersangkutan. Sementara itu adalah bermanfaat bagi administrasi pengadilan apabila tahap-tahap prosedur yang tidak esensial dapat dihindari. Penundaan penuntutan bersyarat ini merupakan suatu alat untuk mewujudkan tujuan - tujuan pidana bersyarat tetapi pada tahap permulaan proses pidana. Penundaan penuntutan menempati posisi menengah antara penarikan kembali tuntutan secara absolute dan pidana bersyarat. ${ }^{9}$ Dari kedua contoh kebijakan preventif yang dikemukakan diatas jelas terlihat bahwa, hal itu memang tidak secara khusus untuk menghadapi kekakuan dari sistem perumusan ancaman pidana yang bersifat imperatif, khususnya perumusan tunggal. Oleh karena itu kebijakan yang demikian perlu diimbangi dengan menyediakan perumusan kebijakan represif.

Dengan kebijakan represif dimaksudkan, suatu kebijakan yang ditetapkan oleh undang-undang untuk memperlunak penerapan sistem perumusan pidana penjara yang bersifat imperatif dan absolut. Termasuk perumusan kebijakan represif misalnya perumusan mengenai pidana bersyarat dan perumusan pedoman bagi hakim dalam menetapkan pidana penjara yang dirumuskan secara imperatif, baik berupa perumusan tunggal maupun perumusan kumulatif. Dengan demikian ketentuan ini dapat dilihat sebagai "katup pengaman" (Veiligheidsklep) yang memang diperlukan dalam setiap sistem, termasuk sistem pidana khususnya dalam menghadapi sistem pidana yang kaku.

\footnotetext{
${ }^{9}$ Ibid, hal. 96-97
} 
Berdasarkan uraian diatas, memiliki harkat dan martabat dapatlah ditegaskan bahwa dilihat dari sudut kebijakan sebagai manusia seutuhnya dan untuk memberikan perlindungan pengoperasionalan pidana penjara, ketentuan pidana bersyarat selama ini perlu ditinjau kembali untuk memperlunak atau mengimbangi sistem perumusan pidana penjara yang bersifat imperatif dan absolut, maka harus ada ketentuan yang memungkinkan pidana bersyarat dijatuhkan secara imperatif dalam hal-hal tertentu khususnya terhadap anak-anak.

Dalam Undang - undang No.

11 tahun 2012 tentang sistem peradilan pidana anak lebih mengarah pada kebijakan preventif, hal ini terlihat dalam penjatuhan pidana dan tindakan yang diatur dalam pasal-pasal berikut antara lain: Pidana tindakan terdapat dalam pasal 69, pasal 70, pasal 71dan pasal 72 UU No.11 tahun 2012 tentang Sistem Peradilan Pidana Anak.

\section{Kesimpulan}

a. Ide dasar keadilan restoratif dalam sistem peradilan pidana anak adalah ditinjau dari aspek filosofis yaitu: Anak merupakan amanah dan karunia Tuhan Yang Maha Esa yang 
b. Kebijakan formulasi keadilan restoratif dalam Undang - Undang No. 11 tahun 2012 tentang Sistem Peradilan Pidana Anak merupakan suatu kebijakan preventif yaitu kebijakan yang diberikan oleh undang-undang kepada aparat penegak hukum untuk mencegah atau tidak mengajukan tersangka ke pengadilan. Sesuai dengan landasan filosofis yang terdapat dalam Undang - undang ini yaitu untuk memberikan perlindungan hukum terhadap anak yang berhadapan dengan hukum, dalam upaya mewujudkan keadilan restoratif (pemulihan) melalui upaya diversi dari proses penerimaan laporan oleh pihak kepolisian sampai proses pemeriksaan di sidang pengadilan. Hal ini dilakukan untuk mencegah kemungkinan besar terdakwa dikenakan pidana penjara sehubungan dengan adanya sistem perumusan ancaman pidana penjara yang bersifat imperatif. Kebijakan ini dapat ditempuh dengan memberikan kewenangan kepada aparat penegak hukum untuk melakukan seleksi terhadap para tersangka yang akan diajukan ke pengadilan walaupun orang itu jelas-jelas telah melakukan suatu tindak pidana.

\section{Saran}

Dengan dikeluarkannya UU No. 11 tahun 2012 Tentang Sistem Peradilan Pidana Anak di Indonesia, sebaiknya diikuti pula dengan mempersiapkan sarana prasarana yang memadai seperti ruang pemeriksaan khusus untuk anak, ruang tahanan anak yang terpisah dari tahanan orang dewasa, serta sumber daya manusia (SDM) yang terlatih/profesional dan mempunyai minat khusus terhadap perlindungan anak agar terwujud keadilan Restoratif.

Sebaiknya ide dasar keadilan restoratif dijadikan landasan dalam perumusan setiap Undang-undang kedepannya. Tidak hanya diberlakukan untuk anak-anak tetapi dapat menjadi pertimbangan terhadap setiap orang yang melakukan pelanggaran hukum dengan ancaman pidana dibawah 5 (lima) tahun, dengan kriteria jenisjenis perbuatan yang tergolong tindak pidana ringan tanpa menyampingkan asas legalitas dan rasa keadilan masyarakat. 


\section{DAFTAR PUSTAKA}

Kasubdit IV, Kepolisian Negara RI Daerah Bali Dir. Reserse Kriminal Umum

Konvensi Hak Anak (UN's Convention on the Rights of the Child) tanggal 20 November 1989.

Barda Nawawi Arief III, 1998, Beberapa Aspek Kebijakan Penegakan dan Pengembangan Hukum Pidana, PT.Citra Aditya Bakti,Bandung.

Minoru Shikita, 1982. Integrated Approach to Effective Administration of Criminal and Juvinille Justice, dalam Criminal Justice in Asia, UNAFEI.

Karl O. Christiansen,1974. Some consideration on the Possibility of a Rational Criminal Policy. Resource Material Series No.7, UNAFEI, Tokyo. Hal. 74: "Criminal policy must combine the various preventive machine and finally coordinate the whole into an organized sistem of state activity"

Hiroshi Ishikawa, 1984. Characteristic Aspects of Japannese Criminal Sistem - A Succesful Example of Integrated Approach, Seminar on the Prevention of Crime and the Treatment of Offenders, January 1984. 